\title{
How Much Do Taxes Discourage Incorporation?
}

\author{
by \\ Jeffrey K. MacKie-Mason \\ and \\ Roger H. Gordon \\ University of Michigan and NBER
}

April 18, 1996

\begin{abstract}
The double taxation of corporate income should discourage firms from incorporating. We investigate the extent to which the aggregate allocation of assets and taxable income in the U.S. between corporate and non-corporate firms responds to the size of this tax distortion during the period 1959-86. In theory, profitable firms should shift out of the corporate sector when the tax distortion is large, and conversely for firms with tax losses. Our empirical results provide strong support for these forecasts, and imply that the resulting excess burden equals $16 \%$ of business tax revenue.
\end{abstract}

Address. Department of Economics, University of Michigan, Ann Arbor, MI 48109-1220. Email: MacKie-Mason: jmm@umich.edu; Gordon: rgordon@umich.edu. 


\title{
How Much Do Taxes Discourage Incorporation?
}

\author{
Jeffrey K. MacKie-Mason \\ and \\ Roger H. Gordon
}

One of the most basic distortions created by the double taxation of corporate income in the U.S. is the disincentive to incorporate. However obvious this distortion may be, most papers investigating the distortions created by the corporate tax have taken as exogenous a firm's choice whether or not to incorporate, assuming for example that some industries are inherently corporate while others are inherently non-corporate. A variety of nontax factors, described below, can certainly influence a firm's choice of organizational form, causing some to favor incorporating and others not. But are these nontax factors so dominant that taxes do not in practice influence a firm's choice of organizational form? As Gravelle and Kotlikoff $(1989,1990)$ emphasize, tax-induced changes in firms' choices of organizational form in principle can create large excess burdens. The size of these excess burdens in practice depends on the extent to which firms respond to these tax incentives.

In this paper, we calculate how the tax distortion discouraging firms from incorporating has varied over time, then estimate the extent to which the allocation of assets and taxable income between corporate vs. non-corporate forms of organization has shifted in response to this timevarying tax distortion. We do this using aggregate data, by industry, in the U.S. during the period 1959-86, then use our estimates to project the effects of the 1986 tax reform on the size of the corporate sector.

In theory, taxes should induce profitable firms to shift out of the corporate sector when the tax distortion to incorporating increases, and conversely for firms with tax losses. Our empirical results provide strong support for these theoretical forecasts, and hold consistently across a wide variety of specifications and measures of the tax variables. We also find that some non-tax-rate policy changes caused shifts in the predicted directions between various forms.

The measured effects are relatively small, however. For instance, cutting the tax rate on non-corporate income by .10 is forecasted to cause $.2 \%$ of total assets to shift out of corporate form. The effect is larger for the location of taxable gains and losses, with the same tax change leading to a shift of approximately $3 \%$ of gains and $4 \%$ of losses toward the more favored forms of 
organization, and in the process generating an excess burden that we estimate to be $16 \%$ of the tax revenue raised from business income. Overall, non-tax factors appear to be dominant in the choice of organizational form, though further research will be needed to determine which factors are most important.

In the first section of this article we present a theoretical characterization of the incentives to choose one organizational form over another. We specify the relationship between specific tax rate parameters and any non-tax benefits (or costs) of using the corporate form. We also discuss the effects of various non-rate tax system effects. In section two we present our empirical analysis. We describe the data, our empirical specification, and our estimation results, then discuss in some detail the interpretation of the results. We consider a variety of alternative explanations. We then estimate the social welfare cost of the differential tax treatment across organizational forms that is implied by our econometric analysis, and summarize the findings in section three.

\section{I . Theoretical Framework}

\section{A. Model of a Firm's Choice of Organizational Form}

We begin with a simple model that determines the equilibrium allocation of resources across different organizational forms as a function of tax rates and non-tax factors. For now we leave "nontax factors" largely unspecified; we return to them in section I.C. For simplicity, we allow for only two classes of ownership: one that is taxed at both the corporate and personal level ("corporate") and another that is taxed only at the personal level ("noncorporate"). The doubletaxation of corporate income has been the focus of studies of corporate debt/equity decisions; we examine its role in the determination of ownership structure.

If there were no taxes, when should a firm choose to incorporate? Assume that a firm, if it is noncorporate, would earn economic income of $I$. If instead it incorporates, its economic income would change to $I+g$ due to a variety of nontax differences between the corporate and noncorporate forms of organization that affect the profitability of the firm. ( $g$ can be negative and will vary by firm). Without tax distortions, firms would incorporate if $g>0$, and conversely.

But the tax law treats income of corporate and noncorporate firms differently. In particular, a noncorporate firm would have taxable income of some amount $I_{x}$ which would be subject to tax as 
ordinary personal income of the partners/proprietors. Denote the personal tax rate on this income by $\tau_{N}$. A noncorporate firm's net-of-tax income is therefore $I-\tau_{N} I_{x}$.

If the firm incorporates, its income is subject not only to corporate taxes but also to personal taxes on any resulting payouts to shareholders or any realized capital gains. In addition, the definition of taxable income under the corporate tax differs in a variety of detailed ways from that faced by noncorporate firms.

We capture the effects of any differences in the definition of taxable income by adjusting the tax rate appropriately. In particular, assume that if a firm incorporates it generates taxable income of $I_{X}+g$ which is taxed at an effective corporate tax rate of $\tau_{C}$. Shareholders in the corporation then face personal income taxes on the income left after corporate taxes - dividend income is taxed at ordinary rates while capital gains are taxed at lower rates. The specific tax rates, of course, vary by investor. However, as shown, for example, in Gordon and Bradford (1980), when a firm's equity is traded freely in the financial markets, without constraints, then the implicit personal tax rates affecting firm behavior can be expressed as a weighted average of the tax rates faced by each individual investor in the firm. Let $\tau_{E}$ represent the implicit personal tax rate per dollar of equity income, taking as given the division of this income between dividends and capital gains. Also, let $\tau$ denote the overall effective tax rate on corporate income, so that $\tau \equiv \tau_{C}+\left(1-\tau_{C}\right) \tau_{E}$. A corporation's net-of-tax profits equals $I+g-\tau\left(I_{x}+g\right)$.

The net cost from incorporating therefore equals

$$
C O S T=-g(1-\tau)+I_{x}\left(\tau-\tau_{N}\right)
$$

In general, this expression (and each term) can be of either sign. Each of the parameters in this expression can differ by firm, leading some firms to prefer corporate form and others to remain noncorporate.

In general, those firms will incorporate for which

$$
g>I_{x}\left(\frac{\tau-\tau_{N}}{1-\tau}\right) \equiv I_{x} T
$$

The expression in parentheses on the right-hand side measures the size of the tax distortion affecting the choice of organizational form, which we denote by $T$. As a result of this distortion, at least some firms will choose a less efficient organizational form in order to reduce tax liabilities. In particular, 
if the ratio $g / I_{x}$ is distributed across firms with $I_{x}>0$ according to the cumulative distribution function $\Phi^{+}\left(g / I_{x}\right)$ and among firms with $I_{x}<0$ according to the distribution function $\Phi^{-}\left(g / I_{x}\right)$, then this equation implies that the fraction of the profitable firms that choose to be noncorporate will equal $\Phi^{+}(T)$ and the noncorporate fraction among firms with losses will equal $1-\Phi^{-}(T)$.

Note that the relation between $T$ and incorporation is not monotonic. Increasing $T$ lowers the fraction of firms that incorporate among firms with taxable profits $\left(I_{x}>0\right)$, and raises it for firms with $I_{x}<0$. Firms with tax losses $\left(I_{x}<0\right)$ gain more from deducting losses when the tax rate they face is higher.

If $g$ were zero, then expression (2) also implies that if firms have losses during some periods and profits during other periods, then they should change organizational form at the transition point. Similarly, if part of a firm generates negative taxable income while the rest of the firm earns profits, then the firm should try to sell off whichever part is not being taxed at the appropriate tax rate, so that each part can choose the more advantageous organizational form. Tax shelters often seem designed to take advantage of these incentives. A common life history for a firm is to start noncorporate, when high start-up costs cause it to run tax losses, and then to incorporate once the firm becomes profitable.

The key objective of this paper is to measure empirically the impact of changes in the tax distortion $T$ on the aggregate division of business activity between corporate and noncorporate forms, using data from the U.S. during the period 1959-86. Since variation in tax rates has been rather limited, in effect we will be estimating $\partial \Phi^{+}(T) / \partial T$ for firms with tax profits and $1-\partial \Phi^{-}(T) / \partial T$ for firms with tax losses.

In the derivation justifying such an estimation strategy we made a number of simplifying assumptions, however, which merit further discussion. One implicit assumption, for example, is that firms can change their organizational form instantaneously and without cost. Yet there are a variety of tax and other transactions costs of changing organizational form, and limits on the frequency of such changes, that in principle would introduce an intertemporal aspect into the analysis. In principle, therefore, firms should base organizational form decisions on future as well as current incentives, and may not respond to potential tax gains that are too small or too temporary to justify the transactions costs of a change in form.

Not all means of shifting the composition of activity between corporate and noncorporate forms of ownership generate such transactions and tax costs, however. Investment rates can differ, for 
example, between existing corporate vs. noncorporate firms without generating transactions costs, and in the process change the relative sizes of the two sectors. In addition, new firms can choose between organizational forms without incurring extra transactions costs at that date. Exit rates could also differ between corporate and noncorporate firms. Transactions costs and limitations are important primarily for certain changes of organizational form by existing firms, and these changes explain only part of the aggregate shifts between corporate and noncorporate status. To test for evidence of transactions costs, however, we try including future as well as current tax rates in the analysis, and test for a gradual response to past tax changes.

Another simplifying assumption is that $\tau_{N}$ is the same for all taxpayers in a given year. Yet, the personal income tax generates important differences in effective personal tax rates across investors. Behavior should differ across tax brackets — a firm whose owners face very high personal tax rates would choose to be noncorporate only if it generates sufficient tax losses so tax considerations outweigh any nontax factors, whereas a firm whose owners are in low tax brackets would choose the noncorporate form only if its taxable income is high enough. In some specifications reported below, we test for the presence of such variation in effective personal tax rates faced by firms earning positive vs. negative income.

The above derivation also assumed that the cumulative distribution functions, $\Phi^{+}$and $\Phi^{-}$, remain stable over time. Intertemporal variation in these distribution functions creates bias to the extent to which these variations are correlated with changes in the size of the tax distortion. We take several approaches to try to control for possible changes over time in these distribution functions. To begin with, we add a quadratic function of time to the specification. In addition, we will include cyclical indicators to capture changes over time in the distribution of the $I_{x}$. Finally, we will control for key changes in the regulations affecting corporate vs. noncorporate organizational forms to capture important changes in the distribution of $g$. Omitted sources of variation can still potentially affect our estimates, however.

\section{B. Tax Effects Other Than Tax Rates}

The above discussion focused primarily on differences in tax rates affecting different organizational forms. However, there are a multitude of other tax provisions that differ by organizational form. We summarize some of these provisions, even though we are in a position to estimate the effects of only a few of them in the empirical work. 
Rules Governing Election. A business must satisfy some restrictions in order to avoid corporate taxes. Often, for example, firms that are legally organized as partnerships are required by the IRS to pay corporate taxes. In general, a firm will be taxed as a corporation unless it fails two of the following criteria: (1) continuity of life; (2) centralized management; (3) easy transferability of ownership shares; and (4) limited liability.

A firm that is deemed to be a corporation under the criteria above can still avoid the corporatelevel tax if it qualifies for $\mathrm{S}$ corporation status. The main criteria for $\mathrm{S}$ corporation eligibility as of the end of our sample period were: (1) no more than 35 shareholders; (2) no corporate shareholders; (3) not part of an affiliated group; (4) only one class of stock; and, (5) not a domestic international sales corporation (DISC). The rules governing eligibility for S corporation status have changed frequently since $\mathrm{S}$ corporations were created in 1957; we will be examining the effects of a number of these rule changes in section II.

Pensions and Fringe Benefits. Opportunities for tax-deferred savings and fringe benefit deductibility have varied across organizational forms and over time. For example, partners and sole proprietors (unincorporated firms with one owner and unlimited liability) can use individualoriented qualified savings plans such as Keogh accounts. Corporate pension funds have different rules on deduction limits and other characteristics. In addition, more fringe benefits provided to employees are deductible for corporations than for partnerships and sole proprietorships (including, until 1986, health insurance premiums). S corporations have faced corporate tax treatment of fringes during some years, and personal tax treatment during others.

Loss Offsets and At-Risk Rules. One significant advantage for partnerships and sole proprietorships is the ability to offset business losses against other sources of personal income when figuring tax liability. A C corporation can offset losses only against its own past or future profits. Before 1983 S corporation losses faced a third set of rules; since 1983 they are treated the same as $\mathrm{C}$ corporations. Some of our tests below allow the effective corporate tax rate to differ between firms with tax profits and tax losses.

In 1976 "at-risk" rules were applied to partnerships, restricting loss deductions to the amount for which an investor is personally at risk. These rules were a response to the growing use of schemes that leveraged investments by limited partners in order to sell large tax losses to high tax rate investors who could immediately deduct them during the early years of a partnership while 
deferring taxes on gains until years later (when they were taxed at the usually lower tax rate of the at-risk investor). These schemes were particularly prevalent for real estate and leasing deals that took advantage of depreciation and interest deduction rules. At-risk rules were applied to S corporation shareholders beginning in 1978.

$\underline{\text { Passive and Foreign Income. }}$ Before 1982 firms earning passive or foreign-source income were not allowed to register as S corporations. With the U.S. 1986 Tax Reform Act passive losses accruing to partners and $\mathrm{S}$ corporation shareholders could be offset only against other sources of passive income and not against ordinary income. Beginning in 1972 a C corporation could receive favored tax treatment on export business if it qualified as a Domestic International Sales Corporation (DISC). S corporations have never been allowed to obtain DISC treatment.

Capital Gains Provisions. In general, capital gains are taxed more favorably at the personal than at the corporate level, creating an incentive not to incorporate for firms earning substantial income in the form of capital gains. However, under the General Utilities doctrine, $\mathrm{C}$ corporations could separately incorporate an asset before it was sold and then distribute the liquidation proceeds directly to shareholders without incurring capital gains tax at the corporate level. As a result, the tax rate on realized capital gains should have been roughly equivalent for corporate vs. noncorporate firms. The General Utilities doctrine was repealed in 1986, although it took three more years to close several important loopholes.

Alternative Minimum Tax. C corporations face an alternative minimum tax (AMT) when taxable income is low due to substantial tax preference items, but for many years this AMT was not binding on more than a few firms. Noncorporate firms were not subject to the corporate AMT. In 1986 a much stronger AMT was legislated. S corporations are not subject to this tax, which was especially important for firms with substantial tax deferrals and accounting practices that led to large book income relative to taxable income because the AMT included 50\% of that difference in the alternative tax base. However, a new personal-level alternative minimum tax was also instituted in 1986 which is of importance for tax shelter investors with substantial passive losses.

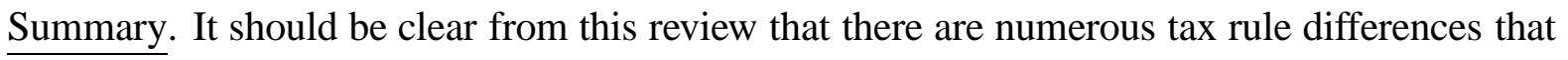
are not easily captured in the formulation of expression (2) but that should affect the allocation of economic resources across organizational forms. In our empirical analysis we exploit the fact that a number of these provisions have changed during our sample period, providing us a limited opportunity to test for their effects. 


\section{Non-Tax Factors}

The two main explanations commonly given for a non-tax advantage, $g$, to the corporate form of organization are first that corporations face limited liability and second that they can trade their shares publicly. How important and convincing are these explanations?

Limited Liability. In principle, corporate shareholders have limited liability, whereas partners and unincorporated sole proprietors have unlimited liability. However, these are only the "default" rules, defining the allocation of liabilities that are not otherwise allocated by explicit contracts through recontracting, these rules can be, and often are, undone. For example, it is very common that the shareholders of small corporations must pledge personal assets if they wish to obtain external bank financing. Partnerships, on the other hand, can write liability limits into contracts with lenders, suppliers, customers and so forth.

The legal difference in the default provisions concerning liability for corporate versus noncorporate firms is therefore important only to the degree that explicit recontracting imposes transactions costs - in some cases, these costs will be large enough that the less favorable rule is left in place. Differences in these provisions are therefore more important when contracting costs are larger.

Even when contracting costs prevent differences in default liability provisions from being undone by explicit contract provisions, it is still not clear whether making limited liability the default provision for corporations favors the corporate form of organization. To the extent that equity holders are better informed than debt holders concerning the future prospects for the firm, then limited liability exacerbates problems created by asymmetric information when firms try to borrow. Conversely if existing shareholders have private information about the firm's potential liabilities (or future prospects) not available to new shareholders, then the lemons problem when shares are sold to new shareholders may be lessened because liability is limited for the new shareholders.

Another complication is that some firms are taxed only at the personal level, yet still have limited liability. One clear example would be subchapter S corporations. Another is limited partnerships. In a limited partnership only the general partner-who may own no more than $1 \%$ of the equity capital—need bear unlimited liability. The limited partners, similar to corporate shareholders, are liable only to the extent of their investment. In fact, the general partner can even be a corporation, 
which bears general liability but only to the limit of the corporation's wealth, with no further recourse to the corporation's shareholders.

Public Trading of Shares. Corporations are also said to have an advantage due to their ability to trade their shares publicly. It is widely agreed that publicly-traded firms have access to lower-cost equity capital. In addition, publicly-traded shares may provide an important instrument for the amelioration of principal-agent problems between managers and owners. In principle, a manager's compensation should be tied to his contribution to the value of the firm. If shares are publicly traded, then the value of the firm (though not necessarily the manager's contribution to it) would be observable continuously, allowing compensation and retention decisions for managers to be tied to performance period by period. In particular, firms commonly tie a manager's compensation to the firm's share value, via share-purchase pension plans, stock options, etc., as documented for example in Murphy (1986). Without public trading of shares, compensation and retention decisions must be based on cruder measures of performance, e.g. accounting information from the firm's income statement and balance sheet. In principle, however, any resulting measurement errors in compensation decisions period by period can eventually be corrected as long as there is an accurate assessment of the value of the firm at the date the manager resigns/retires, similar to a sole proprietor when he sells his business. In the meantime, business decisions may suffer from the fact that they must be based on cruder information about the firm's performance, putting noncorporate firms at a disadvantage.

For the most part, regulations affecting public trading of shares and limited liability for corporate vs. noncorporate firms have not changed over time, nor is there any obvious reason why the economic importance of these differing regulations have changed over time. If so, then whatever their importance we can estimate the effects of tax changes appropriately, using time series data. To protect against gradual changes in regulations (or their economic importance) that may have occurred, we add time trends to all specifications. In addition, we describe below several detailed regulatory changes that did occur during the sample period, and test for their importance in the empirical work. 


\section{II . Empirical Analysis}

We now estimate the degree to which various aggregate measures of the allocation of resources and economic activity across organizational forms has responded as expected to changes in tax incentives. We rely on U.S. tax return data made public by the IRS.

\section{A. Overview and Data}

We use data covering the period 1959-1986. The data are collected from numerous IRS publications and data tapes, and are carefully checked for accuracy. We have measures for about a dozen income statement and balance sheet items as reported to the IRS for $\mathrm{C}$ corporations, $\mathrm{S}$ corporations, partnerships and sole proprietorships. We have data for 7 industry aggregates that correspond to the SIC 1-digit aggregates. For net income, losses and some other variables we have separate data for firms that reported positive net income and firms with losses. Unfortunately, the IRS does not report asset data separately for profit and loss firms for all organizational forms.

We present some descriptive statistics for our dataset in Table I. C corporations control a dominant fraction of business assets in the U.S, but report receiving roughly only two-thirds of business income (both positive income and tax losses). In particular, C corporations control an asset base over 18 times larger than partnerships, yet report on average less than three times as much in losses. Partnerships and $\mathrm{S}$ corporations seem to be biased towards loss activities; e.g., the mean partnership share of total losses is more than two times as large as the partnership share of gains. The standard deviations of each form of organization's share of the annual totals, calculated over 1959-1986, are also listed in Table 1. These changes over time have been quite modest, with the largest variation occurring for firms reporting tax losses.

The effective tax rates, $\tau_{C}, \tau_{E}$, and $\tau_{N}$, can be measured in a variety of ways. Each approach has its own source of measurement errors. We deal with this by constructing two different series for each tax rate, and then using instrumental variables techniques to eliminate possible biases caused by measurement error.

In particular, we use two alternative measures for the effective corporate tax rate, $\tau_{C}$. One simply equals the highest statutory corporate tax rate prevailing in each year. While the true rate may differ from this due, for example, to the lower rates faced on the first $\$ 100,000$ of income for each firm and due to loss-offset provisions, the variation in the effective tax rate over time should 
be dominated by movements in the statutory rate. Our second measure of $\tau_{C}$ equals observed aggregate corporate income tax liabilities (before various credits) divided by aggregate corporate taxable income. This approach, unlike the first, implicitly captures the effects of progressivity in the tax law and to some degree no-loss-offset provisions, but creates an endogeneity problem since aggregate data on corporate taxable income are used in constructing the dependent variable. In addition, it is an ex post measure of the effective tax rate, yet incorporation decisions would be based on ex ante information.

For the personal tax rate on ordinary income $\left(\tau_{N}\right)$, we need a representative tax rate for those potentially investing in noncorporate businesses. One approach is simply to set $\tau_{N}$ equal to the highest statutory marginal personal tax rate in each year. While not all noncorporate owners are in the top tax bracket, this rate should still be highly correlated over time with the effective value of $\tau_{N}$. An alternative approach we use for measuring $\tau_{N}$ is to infer the tax rate of the marginal owner of municipal bonds by comparing the yields on otherwise comparable Treasury and municipal bonds. We use an estimate of this implicit tax rate calculated by Kochin and Parks (1988) and Poterba (1989). While the effective tax rates faced by owners of municipal bonds and noncorporate firms will differ for a variety of reasons, the time series variation in the two should still be highly correlated. Instrumental variables techniques will be used to address any remaining measurement error.

To estimate the personal tax rate on equity income $\left(\tau_{E}\right)$ we assume that the fraction $d$ of nominal income accruing to equity holders takes the form of dividends, and that capital gains are always realized long-term. Then $\tau_{E}=d \tau_{N}+(1-d) \kappa \alpha \tau_{N}$ where $\kappa$ measures the fraction of long-term gains that are taxable, and $\alpha$ is an adjustment to make the capital gains tax rate "accrual equivalent". This captures the benefits from deferring accruing tax liabilities until the asset is sold plus the benefits from the capital gains tax exemption on assets still held at death. Following Feldstein, Dicks-Mireaux, and Poterba (1983), we assume that $\alpha=0.25$. We estimate $d$ by taking the ratio of corporate dividend payments to after-tax corporate profits as reported in the National Income and Product Accounts. We use the statutory time-series for the capital gains exclusion, $\kappa$.

We have two different measures of both $\tau_{C}$ and $\tau_{N}$ (the marginal corporate and personal tax rates). (The measures of $\tau_{N}$ are used to construct two corresponding measures of $\tau_{E}$.) Therefore, we have in principle four different time-series measures of the difference between the total tax 
burden on corporate income and the tax burden on noncorporate income $\left(\tau-\tau_{N}\right)$, which we plot in figure 1. For comparison, in figure 2 we plot the time series for the fractions of book assets, profits and losses reported in corporate form. The main difference between the four tax rate series is in the level and time trend. In particular, the two tax-cost series with $\tau_{N}$ set to the highest statutory personal tax rate trend upwards, while the two series with $\tau_{N}$ set to the implicit tax rate estimated from bond interest rates trend downwards. Year to year variation in each of the four series, in contrast, is highly correlated. To focus on this year to year variation rather than the time trends in the four tax series, we will include a time trend (and time squared) in our regressions.

Figure 1 also reveals a substantial amount of time-series variation in the tax incentives for different organizational forms. It is a truism in the U.S. empirical public finance literature that one cannot estimate regressions using the corporate tax rate because it has changed so little in the postwar era. However, the tax price incentive for allocation of resources across organizational forms depends on the personal tax rates on ordinary and equity income as well, causing the incentive to vary substantially over time.

\section{B. Specifications}

Our theory states that those firms will incorporate for which

$$
g>I_{x}\left(\frac{\tau-\tau_{N}}{1-\tau}\right) \equiv I_{x} T .
$$

If the distribution functions $\Phi^{+}$and $\Phi^{-}$and the fraction of firms with tax losses vs. tax profits are stable across time, then the overall fraction of firms that incorporate should simply be a function of the corporate tax cost $T$. Two controls for possible changes in the distribution of $g$ and $I_{x}$ are the time trend, and the time trend squared, which were added as well to control for uncertainty about the nature of the time trend in the tax distortion. For our basic specification we let $F_{i t}$ represent some measure of the fraction of activity organized in corporate form in industry $i$ in year $t$. We then estimate

$$
F_{i t}=\alpha_{0}+\alpha_{1} \mathrm{TIME}+\alpha_{2} \mathrm{TIME}^{2}+\alpha_{3} T+\epsilon_{i t}
$$

We initially set $F_{i t}$ equal to the fraction of book assets in corporate form, and later explore other measures. The theory implies that increasing $T$ lowers $F_{i t}$ among the subset of firms with $I_{x}>0$ but raises it among firms with $I_{x}<0$. Thus there is no clear forecast for the sign of $\alpha_{3}$ in the full 
sample. But $\alpha_{3}<0$ seems likely since far more assets are held by profitable firms. When equation (4) is estimated on the subsample of firms with taxable losses, however, $\alpha_{3}$ should be positive.

\section{Econometric Method}

Before discussing the results, we should explain our instrumental variables (IV) method. Consider first the two corporate tax rate series: one constructed using the highest statutory marginal rate which we denote by $C_{1}$, and the other using the realized average tax rate which we denote by $C_{2}$. $C_{2}$ should correspond quite closely to the ex post value for $\tau_{C}$. It will have measurement error for several reasons, however. First, the accounting information about taxable income and tax payments differ in a variety of ways from the desired measure. Second, $C_{2}$ is constructed using a measure of corporate taxable income, which is also used in the construction of the dependent variable, introducing a potential endogeneity bias. Third, $C_{2}$ measures the ex post tax rate, yet organizational form decisions are plausibly based on the expected value of this rate judged some period ahead of time. Due to these various sources of measurement error,

$$
C_{2}=\tau_{C}+\epsilon
$$

We assume that $\epsilon$ and $\tau_{C}$ are orthogonal - this would certainly be the case under the third source of measurement error, and seems plausible for the other two sources as well. The statutory tax rate, $C_{1}$ is certainly correlated with the true $\tau_{C}$, but its correlation with $\epsilon$ should be minimal - the statutory tax rate is known ex ante so it is uncorrelated with new ex post information, and it does not depend on taxable income or on any idiosyncrasies in accounting data about taxable income or tax payments. Therefore, it makes a suitable instrumental variable.

Similarly, we have two separate measures of the personal tax rate, $\tau_{N}$ : the highest statutory personal tax rate which we denote by $P_{1}$, and the implicit tax rate embodied in the tax-exempt interest rate, denoted by $P_{2}$. The latter measure should provide a better approximation to the true tax rate, $\tau_{N}$, but will still suffer from several sources of measurement error. For one, the relative values of the effective tax rates on municipal bonds and on noncorporate income can change over time, due, for example, to changing wealth distributions. In addition, $P_{2}$ depends in part on expectations for future tax policy. While $P_{1}$ will certainly be highly correlated with $\tau_{N}$, it should not be correlated with these other factors contaminating the measure $P_{2}$. By the same argument, therefore, $P_{1}$ seems to be an appropriate instrument for $P_{2}$. 
Denote the measure $T$ based on $C_{2}$ and $P_{2}$ by $T_{2}$, and the measure based on $C_{1}$ and $P_{1}$ by $T_{1}$. Our strategy is then to use $T_{2}$ as our measure of $T$, recognizing that it suffers from various sources of measurement error, and then to use $T_{1}$ as an instrumental variable in order to avoid any resulting bias due to these measurement errors.

\section{Results}

In Table II we present coefficient estimates for equation 4 , defining $F_{i t}$ to equal the fraction of total assets held by $\mathrm{C}$ corporations, aggregated across all industries and across firms with both taxable profits and taxable losses. Column 1 reports estimates of equation (4) using OLS, while column 2 reports results using instrumental variables (IV).

The resulting estimates for $\alpha_{3}$ are very small and quite tightly estimated. For example, a 0.1 increase in the tax rate on noncorporate firms raises the fraction of assets invested in the $\mathrm{C}$ corporate form by only 0.2 percentage points. To test for the presence of transactions costs slowing the response of firms to tax rate changes, we also estimate the model with a lagged dependent variable, as justified under a Koyck adjustment process. The results in column 3 show no evidence of any adjustment lag.

The theory forecasts, however, that tax changes should have opposite effects on firms with taxable profits vs. losses. While asset data are not separately available for gain vs. loss firms, we do have separate earnings data on firms with and without taxable profits. In columns 1 and 3 of Table III, we report estimates for equation (4), run separately for loss and gain firms, where the dependent variable is now the fraction of all income (or loss) reported by $\mathrm{C}$ corporations. Otherwise, the specifications are identical to the IV estimates in column 2 of Table II. Once again the results are clearly consistent with the theoretical forecasts. The coefficients on the tax terms in both equations are now much larger. The t-ratio for deficit firms is very high; the precision of the estimate for gain firms is lower, but still significant. Thus, we conclude that the very small response of the aggregate size of the corporate sector to tax changes masks moderate but largely offsetting changes in the behavior of firms with profits vs. losses. For example, at the mean for deficit firms, raising $\tau_{N}$ by .10 would result in $4.2 \%$ of aggregate losses shifting out of the corporate sector. For gain firms the same tax change would cause a shift of $2.8 \%$ of aggregate profits into the corporate sector. 
As a further test for the presence of transactions costs, we added to these two specifications the average value of $T$ during the subsequent three years - when tax changes last longer, firms would be more likely to respond to them, given transactions costs of changing form. The resulting coefficients are reported in columns 2 and 4 of Table III. Here, we find weak support for the importance of transactions costs. Among loss firms the response to a tax change is about $40 \%$ larger if it lasts for at least four years rather than ending after one year. For gain firms, there is no apparent change in the effect.

One way to check the robustness of these results is to estimate the model on just the allocation of income and losses between $\mathrm{C}$ and $\mathrm{S}$ corporations. As described earlier, some of the non-tax differences between $\mathrm{C}$ corporations and partnerships do not exist between $\mathrm{C}$ and $\mathrm{S}$ corporations. Both have limited liability, suggesting more sensitivity to tax effects in this restricted sample. On the other hand, the $\mathrm{S}$ corporate form has strong restrictions on the number and type of owners. When we estimate the model on the fraction of corporate income or loss reported in $\mathrm{C}$ corporate form, we continue to find a negative effect of taxes for gain firms (the t-ratio was -1.83 ) and a positive effect for loss firms (the t-ratio was 4.84). The magnitudes of the coefficients are only about $25 \%-30 \%$ as large as the corresponding coefficients in Table III, however, suggesting that restrictions on the number and type of shareholders are very costly for most firms.

Similar results are found when the sample is disaggregated by one-digit industry. These results are reported separately for firms with profits vs. losses in Table IV. (To save on space, we report just the estimates of $\alpha_{3}$.) The pattern of shifting is consistent with the aggregate results. In only three cases out of fourteen are the signs of the coefficients contrary to the theoretical forecasts and only one of these three is statistically significant.

We also test our restrictions that the coefficients on the corporate and personal tax costs are the same (except for sign). When we re-estimate the regressions by industry in Table IV with the two tax variable components entered separately, the coefficients on both $\tau$ and $\tau_{N}$ continue to have the expected signs, and about the same size as in Table IV. There are two industries for which gain firms have statistically different (at the 5\% level) coefficients, and two other industries that are significantly different for loss firms.

In addition, we test whether the relative weight on $\tau$ vs. $\tau_{N}$ is smaller in the sample of loss firms than in the sample of firms with positive profits. Plausibly, the effective corporate tax rate 
faced by loss firms is lower than for profitable firms due to no-loss-offset restrictions, while the effective personal tax rate on loss firms is higher than for profitable firms since tax shelters tend to be owned by those in the highest tax brackets. In fact, the estimated ratios are essentially identical for gain and loss firms.

We are also concerned that our dependent variable is a fraction constrained to lie between zero and one. To check the sensitivity of our linear specification to this restriction on the error distribution we re-estimate the aggregate and industry equations with the dependent variable in log-odds form, $\ln (F /(1-F))$, under the assumption that $\epsilon_{i t}$ follows a Weibull distribution. This has no appreciable effect on the magnitude or significance of our results. We report the linear specification because it is much easier to interpret, and the linear specification provides a close approximation to the effect from a nonlinear function given the limited variation in the dependent variable.

As a robustness check, we also estimate our regressions, separately for profit and loss firms, using as the dependent variable the fraction of returns filed by corporations, both aggregated and disaggregated by industry. The signs on the tax price effects follow the pattern of signs reported above in Tables III and IV, but the coefficient estimates are nearly always statistically insignificant.

Altogether we find very strong evidence that, as the theory forecasts, both assets and annual gains and losses are shifted across organizational forms in response to changes in the relative tax costs imposed on those forms. The direction and magnitudes of the effects are measured quite consistently across a wide variety of models.

\section{E. Role of the Time Trends}

The time trend variables in the above regressions have nontrivial coefficients, and their inclusion does affect the estimated value and statistical significance of $\alpha_{3}$. If, for example, we re-estimate all of the regressions without the time trend variables, the estimates of $\alpha_{3}$ become statistically insignificant. Much of the explanatory power in the initial regression comes from the time trends. We therefore try to explore further what factors the time trends may be proxying for.

One possible role for the time trends is to pick up the effects of changes in $I_{x}$ over time - when $I_{x}$ is larger in absolute value relative to $g$, tax considerations are more important. Since a major factor changing $I_{x}$ is movements in the aggregate economy, we use an estimate of the deviation 
between GNP and its long-run trend as a control for business cycle factors. Due to problems in inflation accounting, $I_{x}$ will also depend on the inflation rate, so the rate of change in the producer price index is also added as a control variable.

Another possible role of the time trend is to capture factors causing $g$ to change over time. We developed a chronology of some of the more significant policy changes between 1959 and 1986 that we believe may affect the choice of organizational form without directly affecting our measure of $T$. From a long list of changes (in nearly every year) we select three years in which the changes seem to have a clear impact on the size of $g$, and two other years in which the changes were clearly important but had effects in two directions making it difficult to predict ex ante the magnitude or direction of the effects. We describe these policy changes in Table V.

Most of the changes described in the Table concern rules for $\mathrm{S}$ corporations. S corporate status was first introduced in 1957, and most of the changes were incremental liberalizations of the initial restrictions faced by $\mathrm{S}$ corporations. Thus, the predicted effects are the same for both gain and loss firms. When $\mathrm{S}$ corporation rules are liberalized, more activity of both sorts should move to $\mathrm{S}$ corporate form. To avoid having our results affected by the start-up transition following the creation of S-corporate status, which seemed in the data to last through 1964, we restrict our sample period to 1965-1986 when testing for the importance of these rule changes. We capture these policy changes using time dummies. Since the policy changes were permanent, the dummies are coded to be one for all years subsequent to the initial year, and zero for all years before. Thus each coefficient estimate represents the average permanent change in the dependent variable following the policy change.

We then reestimate equation (4) separately for gain and loss firms, adding the controls for business cycle and policy changes to the regression. The resulting coefficients on TIME and $\mathrm{TIME}^{2}$ are both insignificant, suggesting that these time trends simply capture the macroeconomic and policy change effects now included explicitly in the regression. The results reported in the first two columns of Table VI therefore drop the proxies TIME and TIME ${ }^{2}$ in favor of the structural control variables. As in previous results, a higher relative corporate tax rate moves losses into corporate form, and gains into non-corporate form. The coefficient magnitudes are higher than in Table III, but the precision is not very high in the regression for gain firms. There is no evidence that the business cycle or inflation play any role in organizational form decisions. Several of 
the coefficients on the policy change variables are large and statistically significant, and have the expected (or a plausible) sign, while none of the significant coefficients has an unexpected sign. While the number of coefficients being estimated is high enough relative to the number of observations that we do not want to put undue weight on these results, the coefficient estimates remain very much consistent with the theoretical forecasts.

\section{F. Efficiency Implications}

Efficiency losses from these tax distortions arise because some firms with $g>0$ choose not to incorporate (while other firms with $g<0$ do choose to incorporate) due to tax factors, thereby incurring real costs in order to avoid transferring money to the government. To use our empirical results to estimate the size of the efficiency losses arising from tax distortions to organizational form, we proceed as follows. When $T$ changes by $d T$, some firms change their form of organization. By equation (2), we know that for these firms $g / I_{x}=T$. Then, the efficiency loss generated by profitable firms shifting to noncorporate form and loss-making firms shifting to corporate form as $T$ increases by $d T$ equals

$$
-T\left(\frac{\partial I_{c}^{+}}{\partial T}+\frac{\partial I_{c}^{-}}{\partial T}\right) d T
$$

where $I_{c}^{+}\left(I_{c}^{-}\right)$measures aggregate taxable profits (losses) in the corporate sector and where $\partial I_{c} / \partial T$ measures the change in either taxable income figure that results when $T$ increases. Let $\alpha_{3}^{+}\left(\alpha_{3}^{-}\right)$denote our estimate for the change in the fraction of taxable income (losses) that arise in the corporate sector when $T$ changes. Then, $\partial I_{c}^{+} / \partial T=\alpha_{3}^{+} I^{+}$, and $\partial I_{c}^{-} / \partial T=\alpha_{3}^{-} I^{-}$, where $I^{+}$ $\left(I^{-}\right)$measures aggregate profits (losses) for all businesses, corporate and noncorporate. Therefore, the aggregate efficiency losses, $L$, generated by the tax distortion to the choice of organizational form equals

$$
L=-\int_{0}^{T} s\left(\alpha_{3}^{+} I^{+}+\alpha_{3}^{-} I^{-}\right) d s=-.5 T^{2}\left(\alpha_{3}^{-} I^{-}+\alpha_{3}^{+} I^{+}\right) .
$$

Given the estimates for $\alpha_{3}^{+}$and $\alpha_{3}^{-}$that appear in Table 3, and using the observed values of $I^{+}$ and $I^{-}$for 1986, we find that the aggregate efficiency loss equals 2.06 billion dollars, or $22 \%$ of the tax revenue actually collected from corporate and noncorporate firms that year. Over the full sample period, on average, the efficiency loss was $16 \%$ of tax revenue raised. This estimate of the efficiency loss is slightly larger than the figures reported in Gordon and MacKie-Mason (1994), 
where the loss is estimated as $17 \%$ of tax revenue in 1986 and $9 \%$, on average, during the period 1970 to 1986.

Our results differ dramatically from those in Gravelle and Kotlikoff (1990) (hereafter GK), who calculate in their base case that the excess burden generated by the tax distortion to the choice of organizational form equals $109 \%$ of the revenue raised. Their estimates are based on implausible forecasts of the fraction of firms that are initially corporate and the sensitivity of the composition of firms across organizational forms to tax factors. Based on our replication of the model simulations from GK (1990), they assume in their base case that the corporate share of total assets starts at the implausibly low figure of $36 \%$, suggesting a serious benchmarking problem. The corporate asset share then jumps to $99 \%$ if the tax distortion is removed. The Statistics of Income data show, in contrast, that on average $93.8 \%$ of assets had been corporate during the period 1959-86, and our empirical estimates in Table II forecast that the corporate share would increase by only $0.6 \%$ if the tax distortion were eliminated. In any case, the size of the tax distortion varies substantially during the sample period, as seen in Figure 1. However, the maximum and minimum corporate shares of total assets differ by less than 7 percentage points during this period, compared to the massive shifts the GK model would predict with that much tax price variation.

\section{G. Possible Effects of Income Shifting}

One complication not addressed so far is the possibility of income shifting between the corporate and the personal tax base. Given the differences between the corporate and the personal tax rates, firms would gain by shifting taxable income towards the tax base facing the lower tax rate, even holding fixed the ownership of capital. When the corporate rate is higher, this can be done, for example, through use of debt finance. The resulting tax savings lessen the tax disadvantage faced by corporations. However, the process of income shifting generates nontax costs, e.g. bankruptcy costs, that partly (and at the margin fully) offset the tax savings.

The extent of this income shifting should be a function of the size of $T$, implying that the small observed responsiveness to $T$ found so far may in part reflect the fact that our measure of $T$ overstates the tax disadvantage faced by corporations because it ignores the possibility of income shifting. In particular, if a corporation shifts a fraction $\theta$ of its income from the corporate to the personal tax base, then its tax liabilities are reduced by $\theta I_{x}\left(\tau-\tau_{N}\right)$. The extent of income shifting 
is limited by some offsetting nontax costs. Assume in particular that the firm incurs real costs of $\left|I_{x}\right| C(\theta)$, which for simplicity we approximate by $.5\left|I_{x}\right| \theta^{2} / \gamma$. The value of $\theta$ that maximizes the firm's after-tax profits then equals

$$
\theta=\gamma\left(\tau-\tau_{N}\right) \operatorname{sign}\left(I_{x}\right)
$$

Given this choice for $\theta$, a corporation's profits net of taxes and net of any nontax costs of income shifting would equal

$$
I-I_{x} \tau+.5 \gamma\left|I_{x}\right|\left(\tau-\tau_{N}\right)^{2}
$$

As expected, the possibility of income shifting raises net-of-tax corporate income. Given the possibility of income shifting, a firm chooses to incorporate only if

$$
g>I_{x}\left(\frac{\tau-\tau_{N}-.5 \gamma \operatorname{sign}\left(I_{x}\right)\left(\tau-\tau_{N}\right)^{2}}{1-\tau+.5 \gamma \operatorname{sign}\left(I_{x}\right)\left(\tau-\tau_{N}\right)^{2}}\right) \equiv I_{x} T^{*}
$$

When we reestimate equation (3) using $T^{*}$ instead of $T$, we need to use nonlinear methods in order to estimate $\gamma$. In addition, since income shifting reduces measured income in the corporate sector without changing the capital stock there, we redefine our dependent variable to correct for the effects of income shifting. This reestimation is done separately for firms with profits and firms with losses. The resulting estimates for $\gamma$ are far too large to be plausible, but are insignificant statistically. There is not sufficient variation in the data to allow us to estimate $\gamma$ directly.

In order to judge the possible importance of income shifting for our results, we set $\gamma$ equal to what we view to be a plausible (though arbitrary) value to see how far our previous results might be in error through the omission of income shifting considerations. In particular, we set $\gamma=.7$, which implies that a difference between the corporate and the personal tax rate of $20 \%$ leads corporations to shift $14 \%$ of their income out of the corporate tax base. The resulting estimates for the remaining parameters are reported in Table VII, and indicate somewhat smaller responses to tax distortions than are reported in Tables II and III. These estimates would imply that the excess burden from distortions to organizational form are $15 \%$ of observed corporate plus noncorporate tax payments in 1986, and $12 \%$ of tax payments, on average, during the whole sample period. In contrast, given our assumption about the value of $\gamma$, the excess burden created by income shifting as measured by $C(\theta)$ equals $3 \%$ of tax revenue in 1986 and $1 \%$ of tax revenue, on average, during the full sample period. 


\section{H. Projections of the Effects of the 1986 Tax Reform}

All the above estimates use data ending in 1986. In fact, we have data through 1990. The coefficient estimates that result when we reestimate equation (4) extending the data set through 1990 appear in Table VIII. As seen in the Table, the fit generally becomes weaker though the results are still consistent with the theory. Inspection of the residuals indicates particularly large residuals in these extra years, suggesting other factors omitted from the model changed in 1986.

In order to shed more light on the changes post-1986, we use the results in columns 1 and 3 of Table III to forecast out of sample the size of the corporate sector during 1987-90. These forecasts, along with the actual figures are reported in Table IX. As seen in the Table, the fraction of profitable firms that are corporate fell almost twice as much as forecast by our regression. The fraction of firms with losses that are corporate, in contrast, was also lower than forecast, though here the forecast errors are much smaller in magnitude.

We have several hypotheses for why the model does not do better in forecasting the effects of the 1986 Tax Reform. To begin with, a major element of the changes in 1986 was a broadening of the tax base and a reduction in tax rates. But our specification ignores changes in $I_{x}$ brought about by changes in the definition of taxable income. Until 1986, changes in the definition of taxable income were relatively minor, so this omission prior to 1986 should not cause many problems. The base broadening in 1986 was substantial, however, and would further discourage firms from incorporating and thereby face double taxation on their now higher taxable income, a consideration we ignore in our specification.

The base broadening in 1986 was sufficient that few firms after 1986 should consistently generate tax (but not real) losses. This points out a problem with our procedure for dividing firms into those expecting profits vs. losses. The data measure the behavior of firms that have tax losses and tax profits ex post. Some of the firms with ex post tax losses would have anticipated generating tax losses ex ante, whereas others may have expected to be profitable yet turned out to be unlucky; similar classification errors can occur in the sample reporting profits ex post. These classification errors attenuate our prior results, since they blur the distinction between our samples of firms with profits vs. losses. Prior to 1986, many firms did systematically generate tax losses, so that the "signal to noise" ratio would still have been sizable. After 1986, however, few firms would anticipate generating tax losses systematically. Yet many firms would still end up having bad years 
on occasion. As a result, the sample of firms with tax losses after 1986 is dominated plausibly by firms that anticipated generating tax profits. These firms would tend to shift out of the corporate sector after 1986, consistent with the results in Table III. Similarly, there would be less attenuation in the behavioral response among firms with positive ex post profits, consistent with the evidence.

Other important changes in 1986 were a strengthening of the corporate alternative minimum tax and the repeal of the General Utilities Doctrine. While the resulting extra tax payments do show up in the average tax rate figure, they are not picked up by the instrument (which simply equals the statutory tax rate). Our procedure again understates the increase in the relative tax burden faced by corporate firms.

A further complication introduced by the 1986 tax reform was the introduction of binding restrictions on the deductibility of passive losses for noncorporate firms and rule changes effectively ending master limited partnerships. These restrictions clearly lower the attractiveness of the noncorporate form. Yet we underestimate the size of the noncorporate sector after 1986, suggesting that this complication is of second order importance.

On net, we observe substantial changes in organizational form choices after 1986. Our forecasts suggest that the changes in tax rates alone may explain roughly half of the observed changes. Many other changes occurred as part of the Tax Reform Act of 1986, whose effects we do not attempt to capture in our empirical specification, that plausibly explain much of the remaining changes in organizational form choices that occurred after 1986.

\section{III . Conclusion}

Our basic hypothesis is simple: profitable firms will shift out of the corporate sector when the tax distortion to incorporating is larger, and conversely for firms with tax losses. Our empirical evidence provides strong and consistent support for this hypothesis: assets, taxable gains and taxable losses all shift across organizational forms in the direction expected in response to changes in tax rates. We test a wide variety of specifications using different measures of the tax variables, different forms of the dependent variable, different econometric methods, and different control variables. Throughout we obtain estimates that support the basic hypothesis; our main results are statistically precise. The implied efficiency losses from the tax distortions during the sample period to the choice of organizational form equals only about a sixth of the tax revenue collected from business income. It appears that non-tax factors dominate the choice of organizational form. 


\section{Footnotes}

*We are grateful to Laura Kalambokidis, Linda Burilovich, Sharon Parrott, David Eaton, Tracy Hudson, Steve Pincus, Bill Boyle from the IRS, and especially Jane MacKie-Mason for assistance in creating the data set for this paper. Yong Yang provided superb econometric support. We received helpful comments from a referee as well as from Jane Gravelle, Joel Slemrod and Mark Wolfson and seminar participants at NBER, Stanford Business School, Hoover Institution, UC Berkeley, UCLA, Rochester Business School, Toronto, and Michigan. Financial support for the data collection was provided by the Office of Tax Policy Research and the Rackham Graduate School at the University of Michigan. The first draft of the paper was written while MacKie-Mason was a National Fellow at the Hoover Institution. Previous versions of this paper were circulated with the title "Taxes and the Choice of Organizational Form." We gratefully acknowledge financial support from National Science Foundation grant SES-9122240.

1. The particulars of our analysis would be different for a fully or partially integrated tax system such as exists, for example, in the United Kingdom. However, in all tax systems we have reviewed, the general feature holds that there are differential taxes across organizational forms.

2. See Fama and Jensen(1983a,b) for a discussion of the role of various nontax factors in the choice of organizational form. In a companion paper, Gordon and MacKie-Mason (1994), we test some of these hypotheses empirically and find, consistent with Fama and Jensen, that industries where the average firm size is large and where firms face more risk are more heavily corporate.

3. For a sole proprietorship, this tax rate simply equals the marginal tax rate of the sole proprietor. For firms with several owners, $\tau_{N}$ will equal a weighted average of the tax rates of each of the owners. See below for a discussion of the effects of variation in $\tau_{N}$ across investors.

4. For example, the relative tax treatment of such items as capital gains, fringe benefits, tax losses, and tax preferences, compared with ordinary income, all differ between corporate and noncorporate firms. Corporate taxable income may also differ for corporate vs. noncorporate firms because corporations intentionally shift income between the corporate and noncorporate tax bases, e.g. through debt finance. In the process, however, they incur offsetting real costs, so that the net gain from such income shifting is limited. For simplicity, we postpone discussion of the effects of income shifting until section II.G. 
5. Of course, firms can choose their dividend payout rate taking into account differences in the tax treatment of dividends vs. realized and unrealized capital gains. By using observed dividend payout rates in calculating $\tau_{E}$, we take into account any realized tax savings that result from the choice of payout rate, though ignore any nontax implications of this choice. The nature of these nontax factors seems to be too poorly understood to justify adding further complications to our measure of tax distortions.

6. $I_{x}$ can be negative for a variety of reasons. First, even if its ex ante value were positive, its ex post value could be negative. Second, for multi-period investments, expected taxable income could be negative in some years and positive in others. Third, even if the real income to equity were positive, this expression equals the real income to the firm minus the nominal income to debt. Finally, even if $I$ were positive, $I_{x}$ could be negative due to the effects of accelerated depreciation, etc.

7. Corporate losses are deducted against current income through consolidation or merger with profitable entities, or against past or future income through carrybacks and carryforwards.

8. When $g$ is nonzero, the value of $I_{x}$ at which the firm changes organizational form becomes $-g / T$.

9. The incentives to engage in this organizational form life cycle have decreased since the passage of the 1986 Tax Reform Act, because of the passive loss restrictions on passive suppliers of equity capital to noncorporate firms.

10. For example, when a $\mathrm{C}$ corporation converts to a partnership or sole proprietorship, it faces recapture of certain tax benefits, the cost of which has varied substantially over time.

11. For example, corporations cannot shift between $\mathrm{C}$ status and subchapter $\mathrm{S}$ status more than once every five years.

12. As a result, firms with extreme levels of taxable income, both positive and negative, should be more likely to become noncorporate. In fact, observed rates of return for noncorporate firms vary much more across firms than do those for corporations. 
13. In a companion paper (Gordon and MacKie-Mason(1994)), we analyze in detail the effects on equilibrium allocations of differences in personal tax rates across investors and differences in taxable income across industries. Given data limitations faced when dealing with such a complex setting, however, this companion paper is limited to simulating the model using plausible values. In contrast, in this paper our objective is to test the model's ability to forecast empirically.

14. The fraction of firms with profits or losses can change without generating problems, though.

15. For a richer discussion see Scholes and Wolfson $(1987,1988,1991)$.

16. For much of the 1980's it was possible to form a master limited partnership (MLP) that had most of the characteristics of a corporation, including limited liability for the partners and publiclytraded ownership shares, yet was taxed as a partnership. However the U.S. 1987 tax law instituted rules that require nearly all master limited partnerships be taxed as corporations, except for the oil, gas and real estate firms. See Gentry (1991) for tests of tax effects using MLP data.

17. Some of these rules have changed since 1986. We summarize changes during our sample period in Table V.

18. Since 1977 five states have legislated "limited liability companies," which have the limited liability of a corporation but pay no corporate-level tax, yet also avoid most of the restrictions on S corporations. The IRS took 11 years to approve partnership taxation for the first of these; we do not yet have any data on their prevalence.

19. In particular, current losses can be used to reduce tax payments on profits in any of the prior three years or in some number of future years. The number of years before loss carryforwards expire has changed over time.

20. We estimate the effects of this change below.

21. On the other hand, there were important exceptions to the at-risk rules that applied to some real estate investments.

22. Income is passive if earned without active management involvement. For example, portfolio income is generally passive, as is a limited partnership interest in a real estate project. 
23. To prevent firms from shifting to $\mathrm{S}$ corporate status just before liquidation in order to avoid corporate-level capital gains taxation, a related provision (Section 1374) was also enacted in 1986 that requires firms that convert to S status to pay tax at the top corporate rate on any "built-in gains" realized during the 10 years following a conversion.

24. From 1990 through 1993, the book income tax was changed to an Adjusted Current Earnings tax, where ACE is taxable income with adjustments for certain tax preference items. The 1993 Tax Act repealed the ACE tax as of 1994.

25. Existing shareholders also have private information about their personal assets. With unlimited liability, the potential losses to any new shareholder depend in part on the personal assets of existing shareholders, since shareholders have joint and several liability. This creates yet a different type of lemons problem, one that is again avoided with limited liability. For further discussion, see Winton(1993).

26. This approach appears to provide partnerships the same limited liability protection as corporations. However, limited partners cannot directly participate in management without losing their partnership tax treatment, creating hidden information and moral hazard costs. Some moral hazard costs of limited partnerships are considered in Wolfson (1985a, 1985b); MacKie-Mason (1987) examines some hidden information costs. See also Fellingham and Wolfson (1985).

27. In some cases, however, noncorporate firms have also been able to trade their ownership shares publicly. For example, during much of the 1980's shares in master limited partnerships could be traded publicly. See Gentry (1991).

28. Individual business tax returns are not available, so we are not able to test individual firm behavior.

29. Because some necessary farm information was not reported by the IRS during the 1980s, we had to remove Industry 1-Agriculture, Forestry and Fishing — from all of our data, leaving us only 7 of the 8 standard industry aggregates.

30. Sole proprietorships are not required to file balance sheets, thus we are forced to exclude them from calculations based on asset data. If we assume that the ratio of depreciation to assets is the 
same for sole proprietorships and partnerships, then sole proprietorships would have $7 \%$ of total assets in the economy and the corporate share would fall to $88 \%$.

31. As shown in Altshuler and Auerbach (1990), the tax code's asymmetric treatment of tax losses can significantly raise the effective tax rate facing a firm.

32. The complication is that the carryforwards and carrybacks that show up in any given year's returns are those arising from losses in other tax years, not from losses occurring that year.

33. We eliminate any resulting inconsistency in the estimation through use of instrumental variables, as discussed below. In any case, the problem is much less important when looking at industry rather than aggregate data, because we use aggregate income to form the average tax rate estimate but industry income to form the dependent variable.

34. Although it is difficult to obtain strictly comparable Treasury and municipal bond series they generally differ in riskiness, as well as in liquidity and call provisions - the Kochin and Parks paper attempts to control for many of the differences.

35. To begin with, while municipal bonds are tax exempt, some noncorporate firms (e.g. sole proprietorships) generate positive taxable income, and thus attract investors in lower tax brackets, whereas other noncorporate firms earn tax losses, and thus attract investors in higher tax brackets. The relative interest rates on taxable and tax-exempt bonds also reflect expected future tax policies, whereas $\tau_{N}$ is a measure of the current effective tax rate.

36. Recent research on optimal trading strategies suggests that the effects of the tax treatment of capital gains may be far more complicated than can be captured with an estimated $\alpha$ that is constant over time. See Gordon and MacKie-Mason (1990) for further discussion. In addition, $\alpha$ should be a function of interest rates, which vary over time.

37. We did not attempt to make use of industry variation in $d$ in the analysis, fearing that such variation could serve as a proxy for other omitted factors affecting the choice of organizational form, e.g. variation in $I_{x}$ by industry.

38. As a result, we will be measuring the response to year-to-year variation in tax incentives, rather than the response to long term trends. Since transactions costs may reduce the response to year-to-year variation, we will also test for the effects of expected future tax rates. 
39. Other controls for variation over time in the distributions of $g$ and $I_{x}$ are explored in section II.E.

40. The accounting treatment of carrybacks and carryforwards has already been mentioned. Corporate tax savings from more generous fringe benefit provisions do not show up in these figures. Also, foreign source income contaminates the measured tax rate.

41. All equations have been estimated with a first-order serial correlation correction. The DurbinWatson statistic after correction in each of these two cases was 1.7. We calculate all standard errors using the heteroskedastic-robust method of White.

42. To calculate this from the coefficients reported in Table II we need to scale the coefficient because the tax term is $\left(\tau-\tau_{n}\right) /(1-\tau)$, as shown in equation (3).

43. Firms are therefore divided between the two samples based on their ex post taxable income. Organizational form decisions for each year would normally be made before ex post income is known, however. Given the uncertainties faced by firms, some firms expecting positive taxable income may end up with ex post losses, and conversely. Differences in behavior between the two samples will therefore be somewhat attenuated because of our use of ex post rather than ex ante income for each firm.

44. Of course, given the relatively short length of our annual time series, we are severely constrained in our ability to estimate long-term effects. Indeed, the point estimates of the magnitudes were noticeably sensitive to the choice among various asymptotically consistent estimators.

45. One possible explanation for the increase in the corporate share among profitable Financial and Real Estate firms when $T$ increases is that firms with positive ex post profits in this industry are dominated by firms that expected ex ante to have taxable losses and acted accordingly.

46. The industries with significant differences on the two tax price components are manufacturing and trade for gain firms, and mining and construction for loss firms.

47. That is, we allow for separate coefficients on both $\tau$ and $\tau_{n}$, rather than a single coefficient on $T$, and then compare the ratios of these coefficients across loss and gain firms. 
48. For loss firms, the coefficient even changes sign.

49. The $R^{2}$ of the AR1-transformed data for the gain (loss) firms was $0.55(0.88)$ in Table II, and fell to $0.30(0.53)$ when only the time trends are included in the specification.

50. They apparently are not proxying for mismeasurement in the time trend in $T$ - the time trend coefficients in the OLS regression are essentially unchanged when we measure $T$ using $C 1$ and $P 1$ rather than $C 2$ and $P 2$.

51. Inflation also increases the effective capital gains tax rate, an effect not captured in our measure of $T$.

52. We are grateful to Linda Burilovich for her excellent assistance in preparing this chronology. Naturally, our chronology is not a complete catalog of all changes that may have had some relevance for choice of organizational form; we use our judgment to select those changes that we expected to be most important. We also focus exclusively on rules affecting domestic firms, because almost no multinationals are organized in noncorporate form. In any case, we do the selection before running any statistical tests on the data; we do not choose those changes that "fit best."

53. Most of the changes should be self-explanatory, or are explained in section I.B of the paper. One exception is the debt reclassification relaxation for $\mathrm{S}$ corporations in 1973 . When corporations- $\mathrm{C}$ or S-borrow substantial sums from their shareholders, there is a risk that the IRS will deem those loans to be the taxable equivalent of non-voting equity shares, thereby ruling the "interest" payments to be dividends and ineligible for the interest deduction. Since $\mathrm{S}$ corporations were allowed to have only one class of stock, debt reclassification could make a corporation ineligible for S status. The IRS essentially stopped debt reclassifications for S corps in 1973, making S status more viable for many firms.

54. This related study develops a detailed model of the implications of differences in $\tau_{N}$ across taxpayers and differences in $I_{x}$ by industry for the equilibrium choices of organizational form, and then uses plausible parameter values to estimate the resulting efficiency loss from this distortion.

55. Gravelle and Kotlikoff obtain quite similar results in another paper (1989) as well. 
56. The GK estimate is obtained from a simulation model, and thus is subject to a different sort of measurement error problem than is ours.

57. With other parameter choices, the corporate share of assets is predicted, by their model, to jump to $73 \%$ if the corporate tax is removed, implying an aggregate excess burden equal to $40 \%$ of tax revenues.

58. As we note earlier, this is an overestimate because it excludes sole proprietorship assets. We roughly estimate the true corporate asset share at $88 \%$.

59. By making these real costs proportional to the absolute value of taxable income, we assume that the optimal value of $\theta$ does not vary systematically with firm size, as measured by the absolute value of $I_{x}$.

60. In particular, the dependent variable is set equal to $I_{c} /\left[1-\gamma\left(\tau-\tau_{n}\right) \operatorname{sign}\left(I_{c}\right)\right]$ divided by the sum of this figure and income in the noncorporate sector.

61. Existing empirical evidence, as summarized for example in Gordon and MacKie-Mason (1990), suggests that corporate financial policy is in fact much less responsive than this to tax distortions. 


\section{References}

Altshuler, Roseanne. and Alan J. Auerbach, 1990, The Significance of tax law asymmetries: an empirical investigation, Quarterly Journal of Economics 105, 61-86.

Fama, Eugene F. and Michael C. Jensen, 1983a, Separation of ownership and control, Journal of Law and Economics 26, 301-26.

Fama, Eugene F. and Michael C. Jensen, 1983b, Agency problems and residual claims, Journal of Law and Economics 26, 327-49.

Feldstein, Martin S., Louis Dicks-Mireaux, and James Poterba, 1983, The effective tax rate and the pretax rate of return, Journal of Public Economics 21, 129-58.

Fellingham, James and Mark A. Wolfson, 1985, Taxes and risk sharing, Accounting Review 60, $10-17$.

Gentry, William, 1991Taxes, financial decisions and organizational form: evidence from publicly traded partnerships, Working Paper, Department of Economics, Duke University.

Gordon, Roger H. and David F. Bradford, 1980, Taxation and the stock market valuation of capital gains and dividends: theory and empirical results, Journal of Public Economics 14, 109-36.

Gordon, Roger H. and Jeffrey K. MacKie-Mason (1990) "Effects of the tax reform act of 1986 on corporate financial policy and organizational form," in Do Taxes Matter?: The Impact of the Tax Reform Act of 1986, ed. Slemrod, J.. Cambridge, MA: MIT Press.

Gordon, Roger H. and Jeffrey K. MacKie-Mason, 1994, Tax distortions to the choice of organizational form, Journal of Public Economics 55, 279-306.

Gravelle, Jane G. and Lawrence J. Kotlikoff, 1989, The incidence and efficiency costs of corporate taxation when corporate and non-corporate firms produce the same good, Journal of Political Economy 97, 749-81. 
Gravelle, Jane G. and Lawrence J. Kotlikoff, 1990Corporate tax incidence and inefficiency when corporate and non-corporate goods are close substitutes, Working Paper, Department of Economics, Boston University.

Kochin, Levis A. and Richard W. Parks, 1988, Was the tax-exempt bond market inefficient or were future expected tax rates negative?, Journal of Finance 43, 913-932.

MacKie-Mason, Jeffrey, 1987Long-term contracts and sequential economic decisions, University of Michigan Working Paper.

Murphy, Kevin J., 1986, Incentives, learning and compensation: a theoretical and empirical investigation of managerial labor contracts, Rand Journal of Economics 17, 59-76.

Poterba, James M., 1989Tax reform and the market for tax-exempt debt, NBER Working Paper No. 2900.

Scholes, Myron. S. and Mark. A. Wolfson, 1987Taxes and organization theory, Working Paper, Stanford Graduate School of Business.

Scholes, Myron S. and Mark A. Wolfson, 1988The effects of changes in tax laws on corporate reorganization activity, Working Paper, Stanford Graduate School of Business.

Scholes, Myron S. and Mark A. Wolfson (1991) Taxes and Business Strategy: A Global Planning Approach. Englewood Cliffs, NJ: Prentice-Hall.

Winton, Andrew, 1993, Limitation of liability and the ownership structure of the firm, Journal of Finance 48, 487-512.

Wolfson, Mark A. (1985a) "Empirical evidence of incentive problems and their mitigation in oil and gas tax shelter programs," in Principals and Agents: The Structure of Business, ed. J. Pratt and R. Zeckhauser. Cambridge, MA: Harvard Business School.

Wolfson, Mark A., 1985b, Tax, incentive and risk-sharing issues in the allocation of property rights: the general lease-or-buy problem, Journal of Business 58, 159-172. 
Table I: Assets, income and losses by organizational form. 1959-1986. Totals are in billions of 1982 dollars. "Percents" give the mean and standard deviation for each form's share of the total over time; e.g., the mean $\mathrm{C}$ corporation share of total assets was $93.8 \%$, with a $2.1 \%$ standard deviation. No asset data exist for sole proprietorships. Source: IRS Statistics of Income publications.

\begin{tabular}{|c|c|c|}
\hline & Mean & Std. Dev. \\
\hline \multicolumn{3}{|l|}{ Assets, all returns } \\
\hline Total Assets & 8050.6 & 2744.2 \\
\hline$\% \mathrm{C}$ corporation & $93.8 \%$ & $2.1 \%$ \\
\hline$\% \mathrm{~S}$ corporation & $1.1 \%$ & $0.2 \%$ \\
\hline$\%$ Partnership & $5.1 \%$ & $2.0 \%$ \\
\hline \multicolumn{3}{|c|}{ Income, firms with net income } \\
\hline Total Income & 405.4 & 84.0 \\
\hline$\% \mathrm{C}$ corporation & $66.9 \%$ & $3.6 \%$ \\
\hline$\% \mathrm{~S}$ corporation & $2.1 \%$ & $0.8 \%$ \\
\hline$\%$ Partnership & $10.1 \%$ & $1.9 \%$ \\
\hline$\%$ sole proprietorship & $20.8 \%$ & $3.4 \%$ \\
\hline \multicolumn{3}{|l|}{ Loss, firms with loss } \\
\hline Total Loss & 86.1 & 65.9 \\
\hline$\% \mathrm{C}$ corporation & $57.5 \%$ & $7.8 \%$ \\
\hline$\% \mathrm{~S}$ corporation & $4.5 \%$ & $0.9 \%$ \\
\hline$\%$ Partnership & $23.5 \%$ & $10.0 \%$ \\
\hline$\%$ sole proprietorship & $14.5 \%$ & $3.8 \%$ \\
\hline
\end{tabular}


Table II: Estimated effect of corporate tax disadvantage on the fraction of assets held by $\mathrm{C}$ corporations. Each column reports the coefficients from a separate regression. "Time" and "Time-squared" are trends; "tax price" is the tax cost of C corporate form relative to other forms. All firms aggregated except agriculture, forestry, fishing. The regressions are based on 25 observations, 1962-1986. (Partnership asset data are unavailable for 1960, so 1959-61 cannot be used with the AR1 method.) All regressions are estimated with a correction for first-order serial correlation, and t-ratios are in parentheses.

\begin{tabular}{rccc}
\hline & \multicolumn{3}{c}{ Statistical Method } \\
\cline { 2 - 4 } & OLS & IV & $\begin{array}{c}\text { IV w/Lagged } \\
\text { Dep. Var. }\end{array}$ \\
& & & 0.9644 \\
Time & 0.964 & $(144)$ & $(4.95)$ \\
& $(1.02)$ & $(1.03)$ & $(0.620)$ \\
Time-squared & $-0.954 \mathrm{E}-4$ & $-0.955 \mathrm{E}-4$ & $-0.913 \mathrm{E}-4$ \\
& $(4.92)$ & $(4.95)$ & $(2.75)$ \\
Tax price & -0.00920 & -0.00946 & -0.00859 \\
& $(1.75)$ & $(3.37)$ & $(2.42)$ \\
Lagged dep. & & & 0.0216 \\
variable & & & $(.108)$ \\
& & & \\
$R^{2}$ & 0.99 & 0.99 & 0.99 \\
Durbin-Watson & 1.71 & 1.70 & 1.75 \\
\hline
\end{tabular}


Table III: Estimated effect of corporate tax disadvantage on the fraction of gains and losses reported by $\mathrm{C}$ corporations. Each column reports the coefficients from a different regression. "Time" and "Time-squared" are trends; "tax price" is the tax cost of $\mathrm{C}$ corporate form relative to other forms; "future tax price" is the average of the three leading values of the tax price variable. "Loss firms" are those reporting negative taxable income; "gain firms" report positive taxable income. All firms aggregated except agriculture, forestry, fishing. The regressions are based on 27 observations, 1960-1986, and are estimated with instrumental variables. Each regression is estimated with a correction for first-order serial correlation, and t-ratios are in parentheses.

\begin{tabular}{rcccc}
\hline & \multicolumn{2}{c}{ Loss Firms } & \multicolumn{2}{c}{ Gain Firms } \\
\hline Intercept & 0.655 & 0.651 & 0.638 & 0.634 \\
& $(13.1)$ & $(9.70)$ & $(8.29)$ & $(7.18)$ \\
Time & -0.0188 & -0.0242 & 0.0128 & 0.0122 \\
& $(4.26)$ & $(4.21)$ & $(1.72)$ & $(1.55)$ \\
Time-squared & -.000276 & 0.000420 & -.000164 & -0.000150 \\
& $(2.25)$ & $(2.68)$ & $(.828)$ & $(.703)$ \\
Tax price & 0.216 & 0.207 & -0.144 & -0.142 \\
& $(4.52)$ & $(4.11)$ & $(2.28)$ & $(2.20)$ \\
Future tax & & 0.086 & & 0.012 \\
price & & $(1.28)$ & & $(.145)$ \\
& & & & \\
R-squared & 0.95 & 0.95 & 0.87 & 0.87 \\
Durbin-Watson & 2.31 & 2.37 & 1.78 & 1.80 \\
\hline
\end{tabular}


Table IV: Estimated effect of corporate tax disadvantage on the fraction of gains and losses reported by $\mathrm{C}$ corporations, by one-digit SIC industry. Each column reports the coefficients from a different regression. "Loss firms" are those reporting negative taxable income; "gain firms" report positive taxable income. All regressions are based on 27 observations, 1960-1986, and are estimated with instrumental variables. All regressions are estimated with a correction for first-order serial correlation, and t-ratios are in parentheses. "Aggregate" reports the means for the aggregate regressions, as detailed in Table III. The other explanatory variables (not reported) were a constant, a time trend and time squared.

\begin{tabular}{rcc}
\hline Industry & Loss Firms & Gain Firms \\
\hline Mining & 0.328 & -1.82 \\
& $(1.59)$ & $(1.04)$ \\
Construction & 0.184 & -0.216 \\
& $(2.26)$ & $(2.27)$ \\
Manufacturing & 0.128 & -0.028 \\
& $(4.78)$ & $(1.40)$ \\
Transportation & 0.157 & 0.0493 \\
& $(1.34)$ & $(.999)$ \\
W\&R Trade & 0.0952 & -0.129 \\
& $(1.67)$ & $(1.64)$ \\
Financial \& Real Estate & 0.0503 & 0.638 \\
& $(0.350)$ & $(2.73)$ \\
Services & -0.0239 & -0.0950 \\
& $(0.0968)$ & $(1.54)$ \\
\hline Aggregate & 0.216 & -0.144 \\
(from Table III) & $(4.52)$ & $(2.28)$ \\
\hline & &
\end{tabular}

Note:

1. The average $R^{2}$ for the reported regressions was 0.64 with a standard deviation of 0.25 . The only regression with an $R^{2}$ less than 0.23 was for Services with losses. The average Durbin-Watson statistic after the Cochrane-Orcutt transformation was 1.77 with a standard deviation of 0.23 . The only regressions with a DurbinWatson statistic less than 1.6 were those for Financial and Real Estate firms, which also produced the one significant and anomalous coefficient estimate in the table. 
Table V: Major non-rate tax policy changes during the sample period. Changes identified from IRS Statistics of Income publications. The last column is our prediction of the direction of the effect that this change will have on the fraction of economic activity organized in $\mathrm{C}$ corporate form.

\begin{tabular}{|c|c|c|}
\hline Year & Changes & $\begin{array}{l}\text { Expected effect on fraction of } \\
\text { activity in } \mathrm{C} \text { corporate form }\end{array}$ \\
\hline 1969 & $\begin{array}{l}\text { S corps allowed to use Keogh-like qualified pension } \\
\text { plans, putting them on parity with partnerships } \\
\text { and sole proprietorships }\end{array}$ & - \\
\hline 1973 & $\begin{array}{l}\text { Debt reclassification restriction on } \mathrm{S} \text { corps almost } \\
\text { completely relaxed }\end{array}$ & - \\
\hline 1976 & At-risk rules implemented, primarily for partnerships & + \\
\hline 1982 & $\begin{array}{l}\text { (a) New S corps cannot own subsidiaries; (b) Limit } \\
\text { on S corp shareholders raised to } 20 \text {; (c) limit removed } \\
\text { on S corp foreign income; (d) limit removed on S corp } \\
\text { passive income; (e) C corp loss carryforward extended } \\
\text { from } 7 \text { to } 15 \text { years }\end{array}$ & $?$ \\
\hline 1983 & $\begin{array}{l}\text { (a) } \mathrm{S} \text { corps restored to pension plan parity with } \\
\mathrm{C} \text { corps; (b) } \mathrm{S} \text { corp shareholder limit raised to } 35 \text {; } \\
\text { (c) } \mathrm{S} \text { corps granted unlimited flow-through loss } \\
\text { carryovers; (d) } \mathrm{S} \text { corps restricted on fringe deductions } \\
\text { by shareholder-employees }\end{array}$ & $?$ \\
\hline
\end{tabular}


Table VI: Estimated effects of tax-rate, regulatory, and macro changes on allocation of income and losses. "Tax price" is the tax cost of C corporate form relative to other forms; "Log GNP deviation" is the natural $\log$ of the deviation of GNP from a long-run trend (obtained from a regression on and intercept, time and timesquared); "inflation rate" is the log rate of change in the producer price index. The years represent dummy variables that are equal to 1 in that year and all following years; zero otherwise. All firms aggregated except agriculture, forestry, fishing. Regressions are estimated on 22 observations for 1965-1986, using instrumental variables. t-ratios are in parentheses. 


\begin{tabular}{|c|c|c|}
\hline & \multicolumn{2}{|c|}{ C corps vs. others } \\
\hline & Loss & Gain \\
\hline \multirow[t]{2}{*}{ Intercept } & .415 & .734 \\
\hline & (7.7) & (13) \\
\hline \multirow[t]{2}{*}{ Tax price } & .377 & -1.06 \\
\hline & (4.4) & $(1.2)$ \\
\hline Log GNP & .623 & -.485 \\
\hline deviation & (1.4) & $(1.1)$ \\
\hline \multirow[t]{2}{*}{ Inflation rate } & .0356 & .190 \\
\hline & $(.26)$ & (1.3) \\
\hline \multirow[t]{2}{*}{1969} & -.122 & -.00913 \\
\hline & $(5.4)$ & $(.41)$ \\
\hline \multirow[t]{2}{*}{1973} & .0154 & .035 \\
\hline & $(.51)$ & (1.1) \\
\hline \multirow[t]{2}{*}{1976} & -.0232 & .0582 \\
\hline & $(1.8)$ & $(4.31)$ \\
\hline \multirow[t]{2}{*}{1982} & -.169 & .0589 \\
\hline & (2.9) & $(1.1)$ \\
\hline \multirow[t]{2}{*}{1983} & .113 & -.0453 \\
\hline & (2.6) & $(1.1)$ \\
\hline R-squared & .95 & .94 \\
\hline Durbin-Watson & 2.30 & 2.25 \\
\hline
\end{tabular}


Table VII: Estimated effect of corporate tax disadvantage on the fraction of assets, gains and losses held in $\mathrm{C}$ corporate form, allowing for income-shifting between the corporate and personal tax base. The cost of shifting income is parameterized with $\gamma=0.7$ (see text). Each column reports a separate regression. "Time" and "Timesquared" are trends; "tax price" is the tax cost of C corporate form relative to other forms. All firms aggregated except agriculture, forestry, fishing. Each regression is based on 25 observations, 1962-1986. (Partnership asset data are unavailable for 1960, so 1959-61 cannot be used with the AR1 method.) All regressions are estimated with a correction for first-order serial correlation, and using instrumental variables. $\mathrm{t}$-ratios are in parentheses.

\begin{tabular}{lccc}
\hline & Assets & Gains & Losses \\
\hline intercept & .967 & .635 & .674 \\
& $(131)$ & $(9.5)$ & $(18)$ \\
time & .000746 & .0146 & -.0190 \\
& $(1.1)$ & $(2.3)$ & $(5.0)$ \\
time-squared & $-.948 \mathrm{E}-4$ & -.000219 & .000278 \\
& $(5.2)$ & $(1.3)$ & $(2.61)$ \\
tax price & -.0169 & -.108 & .097 \\
& $(1.82)$ & $(1.29)$ & $(3.8)$ \\
& & & \\
$R^{2}$ & .97 & .58 & .89 \\
Durbin-Watson & 1.72 & 1.75 & 2.26 \\
\hline
\end{tabular}


Table VIII: Estimated effect of corporate tax disadvantage on the fraction of assets held by C corporations when the sample is extended from 1986 through 1990. "Time" and "Time-squared" are trends; "tax price" is the tax cost of C corporate form relative to other forms. Each regression is based on 29 observations, 19621990. (Partnership asset data are unavailable for 1960, so 1959-61 cannot be used with the AR1 method.) All regressions are estimated with a correction for first-order serial correlation, and t-ratios are in parentheses.

\begin{tabular}{lccc}
\hline & Assets & Gains & Losses \\
\hline intercept & .965 & .336 & .712 \\
& $(187)$ & $(1.9)$ & $(15)$ \\
time & .000777 & .0474 & -.0254 \\
& $(1.4)$ & $(2.8)$ & $(6.1)$ \\
time-squared & $-.966 \mathrm{E}-4$ & -.00104 & .000463 \\
& $(7.3)$ & $(2.9)$ & $(4.55)$ \\
tax price & -.0102 & -.174 & .205 \\
& $(1.64)$ & $(1.84)$ & $(4.06)$ \\
& & & \\
$R^{2}$ & .98 & .25 & .86 \\
Durbin-Watson & 1.64 & 1.87 & 2.44 \\
\hline
\end{tabular}


Table IX: Forecast corporate share of gains and losses, 1986-1990. Forecast calculated using the models reported in the first and third columns of Table III. Forecast errors calculated as predicted minus actual. All firms aggregated except agriculture, forestry, fishing.

\begin{tabular}{lcccc}
\hline & \multicolumn{2}{c}{ Gains } & \multicolumn{2}{c}{ Losses } \\
\cline { 2 - 5 } & Forecast & Error & Forecast & Error \\
\hline 1986 & 0.784 & 0.022 & 0.47424 & -0.014 \\
1987 & 0.786 & 0.067 & 0.45900 & -0.014 \\
1988 & 0.772 & 0.078 & 0.43527 & -0.028 \\
1989 & 0.752 & 0.081 & 0.43466 & -0.046 \\
1990 & 0.728 & 0.083 & 0.45941 & -0.031 \\
\hline
\end{tabular}


Figure 1

Title: Different Measures of Tax Cost of Corporate Form

Caption: The tax cost is calculated as a complex difference between corporate and personal tax rates; see text. Corporate tax rates are measured as either the average rate paid, from the IRS Statistics of Income, (soi), or the top statutory rate (stat). Personal tax rates are either estimated from the price difference between taxable and non-taxable bonds (bond) or as the top statutory rate (stat). There are four possible combinations. They are indicated in the figure legend by first denoting the corporate and second the personal tax rate measure used. For example, "soi/bond" means the tax cost was calculated using the average corporate tax rate and the implicit bond price measure of the personal tax rate. 
Figure 2

Title: C Corporate Shares of Assets, Profits and Losses, 1957-90

Caption: The dependent variables are trended. Calculated as the corporate share of all assets (not available for sole proprietorships), all returns will positive taxable income, and all returns with losses, respectively. Source: IRS Statistics of Income publications. 